\title{
KEBIJAKAN PENILAIAN KEBERHASILAN REKLAMASI LAHAN PASCA-TAMBANG BATUBARA DI INDONESIA
}

\author{
(Policy Study on Post Coal Mining Reclamation Assessment in Indonesia)
}

\author{
Ardiyanto W. Nugroho \& Ishak Yassir \\ Balai Penelitian dan Pengembangan Teknologi Konservasi Sumber Daya Alam Samboja \\ Jl Soekarno-Hatta km 38, Samboja, Kutai Kartanegara, Kalimantan Timur, Indonesia \\ Email: ardiyanto.nugroho@gmail.com, ishak.yassir@gmail.com
}

Diterima 19 Mei 2017, direvisi 27 Oktober 2017, disetujui 6 November 2017.

\begin{abstract}
Indonesian government has enacted regulations requiring reclamation and rehabilitation activities on post coal mining areas. However, the evaluation related to the ecological restoration concepts is yet unavailable. This study aims to evaluate the regulations on rehabilitation and reclamation of post coal mining areas in Indonesia conforming on ecological restoration concepts. Employing desk study and content anaysis, this research focussed on three technical regulations concerning reclamation guidance and post-mining evaluation guidance, namely ESDM Decree No 7 Year 2014, MoF Decree No P.60/Menhut-II/2009, and MoF Decree No P.4/Menhut-II/2011. Each regulation was comprehensively evaluated whether the regulation already regulates matters relating to ecological restoration criterias, such as biodiversity recovery, soil remediation, planting of local plants, bans on invasive plant species and monitoring and evaluation. The result showed that there was no regulation complying with all ecological restoration criterias. Meanwhile, all the regulations have mandated monitoring and evaluation after rehabilitation and reclamation activities. However, there was no regulation mandating prohibition on planting invasive plant species. In conclusion, regulations related to post coal mining rehabilitation and reclamation have not fully complied with the ecological restoration concepts, therefore improvement to that regulations are necessary.
\end{abstract}

Keyword: Ecological restoration; rehabilitation; reclamation; coal mining.

\begin{abstract}
ABSTRAK
Pemerintah Indonesia telah menetapkan berbagai peraturan yang mewajibkan kegiatan reklamasi dan rehabilitasi pasca-tambang, namun, belum banyak dilakukan evaluasi terhadap peraturan tersebut dalam kaitannya dengan konsep ekologi restorasi. Penelitian ini bertujuan untuk mengetahui sejauh mana peraturan-peraturan tersebut memenuhi konsep restorasi ekologi. Metode penelitian ini adalah desk study dengan bahan utama regulasi yang berkaitan dengan kegiatan reklamasi dan rehabilitasi lahan pasca-tambang batubara. Analisis data dilakukan dengan metode analisis isi. Kajian difokuskan pada tiga aturan teknis yang mengatur pedoman reklamasi maupun pedoman penilaian keberhasilan reklamasi pasca-tambang yaitu Peraturan Menteri ESDM Nomor 7 tahun 2014, Permenhut Nomor P.60/Menhut-II/2009, dan Permenhut Nomor P.4/Menhut-II/2011. Setiap peraturan perundangan dikaji secara komprehensif apakah peraturan tersebut sudah memuat dan mengatur hal-hal yang berkaitan dengan beberapa kriteria restorasi ekologi. Hasil penelitian menunjukkan bahwa tidak ada peraturan yang memenuhi semua kriteria restorasi ekologi. Semua regulasi telah memuat kewajiban rehabilitasi atau reklamasi serta evaluasi tetapi tidak ada satupun regulasi yang memuat pelarangan penggunaan tanaman invasif. Kesimpulan penelitian ini adalah regulasi tentang rehabilitasi dan reklamasi pasca-tambang batubara di Indonesia belum sepenuhnya sejalan dengan konsep ekologi restorasi karena hanya memuat sebagian dari kriteria dan indikator restorasi ekologi sehingga masih diperlukan penyempurnaan agar perbaikan dan pemulihan lahan pasca-tambang dapat memenuhi konsep restorasi ekologi.
\end{abstract}

Kata Kunci: Restorasi ekologi; rehabilitasi; reklamasi; tambang batubara. 


\section{PENDAHULUAN}

Umumnya, di Indonesia ekstraksi batubara dilakukan dengan metode pertambangan terbuka (open pitmining system). Secara teknis, metode pertambangan terbuka dilakukan dengan cara vegetasi yang ada dipermukaan tanah dibuka dan kemudian batubara diambil untuk dibawa ke proses selanjutnya. Dampak dari metode pertambangan terbuka selain mengakibatkan permukaan tanah menjadi terbuka, juga lahan menjadi rentan terjadi erosi yang diikuti dengan sedimentasi (Ahmad, 2012; Endriantho, Ramli, Hasanuddin, \& Hasanuddin, 2013; Marganingrum \& Noviardi, 2009). Untuk itu, pemerintah telah mengatur dan mewajibkan bagi seluruh pemegang Izin Usaha Pertambangan (IUP) untuk melakukan kegiatan perbaikan dan pemulihan lahan tambang tersebut sesuai peruntukkannya melalui kegiatan reklamasi dan revegetasi. Terkait dengan upaya perbaikan dan pemulihan lahan pasca-tambang melalui kegiatan reklamasi, pemerintah telah menerbitkan berbagai macam peraturan untuk memastikan bahwa kegiatan reklamasi lahan tersebut wajib dilakukan oleh para pemegang IUP. Selain itu, untuk memastikan keberhasilan dari kegiatan reklamasi tersebut maka pemerintah juga telah mengatur berbagai macam aturan terkait dengan pedoman penilaian keberhasilan reklamasi pasca-tambang.

Di Indonesia, baik pedoman reklamasi pasca-tambang maupun pedoman penilaian keberhasilan reklamasi pasca-tambang diatur melalui kementerian teknis yaitu Kementerian EnergidanSumberDayaMineral(Kementerian ESDM) dan Kementerian Lingkungan Hidup dan Kehutanan (Kementerian LHK). Setidaknya ada 3 (tiga) aturan teknis di tingkat kementerian yang mengatur baik pedoman reklamasi pasca-tambang maupun pedoman penilaian keberhasilan pascatambang. Khusus di Kementerian ESDM, aturan teknis tersebut yaitu Peraturan Menteri (Permen) ESDM Nomor 7 Tahun 2014 tentang
Pelaksanaan Reklamasi dan Pasca-tambang pada Kegiatan Usaha Pertambangan Mineral dan Batubara. Di pihak lain, Kementerian LHK yang sebelumnya Kementerian Kehutanan mengeluarkan Peraturan Menteri Kehutanan (Permenhut) Nomor P.60/Menhut-II/2009 tentang Pedoman Penilaian Keberhasilan Reklamasi Hutan dan Permenhut Nomor P.4/ Menhut-II/2011 tentang Pedoman Reklamasi Hutan. Ketiga peraturan menteri tersebut merupakan peraturan teknis yang disusun untuk menerjemahkan prinsip-prinsip kegiatan reklamasi pada undang-undang, peraturan pemerintah dan peraturan presiden yang ada di atasnya.

Saat ini, meskipun pedoman reklamasi dan pedoman penilaian keberhasilan reklamasi pasca-tambang telah diatur melalui ketiga aturan tersebut, namun belum banyak kajian terhadap kebijakan tersebut apakah pedoman reklamasi dan pedoman penilaian keberhasilan tersebut telah memenuhi prinsip restorasi ekologi terutama pada Izin Usaha Pertambangan (IUP) yang berada dalam kawasan hutan dengan skema Izin Pinjam Pakai Kawasan Hutan (IPPKH). Khusus IUP yang berada dalam kawasan hutan dengan skema IPPKH, pemenuhan prinsip restorasi ekologi menjadi sangat penting mengingat tujuan dari rangkaian reklamasi khususnya di kawasan hutan tersebut tidak hanya semata-mata untuk menata, memulihkan, dan memperbaiki lahan dan vegetasi yang rusak untuk dapat berfungsi kembali sesuai peruntukannya saja, tetapi juga harus mampu memperbaiki dan memulihkan komposisi jenis dan struktur komunitas ekosistem hutan tersebut (Mc Donald, Gann, Jonson, \& Dixon, 2016).

Untuk mengetahui lebih dalam dan juga mengetahui sejauh mana peraturan reklamasi pasca-tambang batubara telah memenuhi prinsip restorasi ekologi maka kajian kebijakan penilaian keberhasilan reklamasi pasca-tambang batubara ini dilakukan. Kajian difokuskan pada 3 (tiga) aturan teknis 
yang mengatur pedoman reklamasi maupun pedoman penilaian keberhasilan reklamasi pasca-tambang, yaitu Permen ESDM Nomor 7 Tahun 2014, Permenhut Nomor P.60/ Menhut-II/2009, dan Permenhut Nomor P.4/ Menhut-II/2011. Hasil kajian diharapkan dapat memberikan informasi sejauh mana komitmen pemerintah dalam konservasi keanekaragaman hayati di lahan pascatambang batubara. Selain itu, diharapkan dari hasil kajian ini akan dapat memberikan masukan kepada pemerintah dalam rangka menyempurnakan pedoman penilaian keberhasilan reklamasi pasca-tambang yang lebih memenuhi prinsip-prinsip restorasi ekologi.

\section{METODE PENELITIAN}

\section{A. Metode Pengumpulan Data}

Pengumpulan data dilakukan pada bulan November 2016 sampai dengan Februari 2017. Penelitian ini menggunakan metode desk study dengan bahan-bahan utama adalah Permen ESDM Nomor 7 Tahun 2014, Permenhut Nomor P.60/Menhut-II/2009 dan Permenhut Nomor P.4/Menhut-II/2011. Akan tetapi, undang-undang, peraturan pemerintah dan peraturan menteri yang berkaitan dengan kegiatan reklamasi lahan pasca-tambang batubara juga dijadikan rujukan dalam penelitian ini (Tabel 1). Untuk peraturan setingkat menteri, terdapat 2(dua) kementerian yang mengeluarkan peraturan yang berkaitan erat dengan kegiatan reklamasi lahan pascatambang batubara yaitu; Kementerian ESDM yang mengatur kegiatan pertambangan baik di dalam kawasan hutan dan Areal Penggunaan Lain (APL); dan Kementerian LHK yang khusus mengatur kewajiban reklamasi pascatambang di dalam kawasan hutan dengan skema IPPKH.

\section{B. Analisis Data}

Peraturan-peraturan yang berkaitan dengan reklamasi dan rehabilitasi lahan pascatambang batubara khususnya Permen ESDM Nomor 7 Tahun 2014, Permenhut Nomor P.60/
Menhut-II/2009 dan Permenhut Nomor P.4/ Menhut-II/2011 dikaji secara kualitatif dengan metode analisis isi (content analysis). Menurut Krippendorff (2004), analisis isi merupakan suatu teknik penelitian untuk membuat kesimpulan yang valid dan dapat diulang dari suatu teks, sedangkan menurut Crowley and Delfico (1996), analisis isi merupakan suatu prosedur untuk menggali dan mengorganisir suatu informasi dari material tertulis (written material) atau terekam (recorded material), kemudian informasi yang diinginkan dari material tersebut direview dan dianalisis secara terstruktur hingga diperoleh suatu kesimpulan. Material tertulis yang dimaksud dapat berupa peraturan, dokumen, kertas kerja, transkrip dan hasil evaluasi. Dalam penelitian ini, setiap peraturan perundangan akan dikaji secara komprehensif apakah peraturan tersebut sudah memuat dan mengatur halhal yang berkaitan dengan kriteria restorasi ekologi. Dalam penelitian ini digunakan 5 (lima) kriteria restorasi ekologi yaitu; remediasi tanah, pemulihan keanekaragaman hayati, penggunaan tanaman lokal, pelarangan penggunaan tanaman invasif, serta monitoring dan evaluasi kegiatan.

Remediasi lahan merupakan elemen penting dalam kegiatan restorasi lahan pasca-tambang (Beesley et al., 2011; Bott et al., 2012). Lahan tambang yang sudah rusak berat perlu diremediasi terlebih dahulu sebelum dilakukan penanaman (Heneghan et al., 2008). Hal ini karena kegiatan tambang batubara di Indonesia menggunakan metode pertambangan terbuka, yaitu lapisan permukaan tanah dibuka kemudian batubara diekstraksi, yang mengakibatkan kondisi lahan pasca-tambang termasuk ekstrim yaitu suhu yang tinggi, kering dengan unsur hara yang kurang dan $\mathrm{pH}$ rendah. Oleh karena itu, kegiatan remediasi tanah perlu dilakukan untuk menciptakan media tumbuh yang layak bagi tanaman saat penanaman.

Pemulihan keanekaragaman hayati (flora dan fauna) juga sangat penting sebagai salah satu elemen dalam kegiatan restorasi lahan 
Tabel 1. Beberapa regulasi terkait dengan reklamasi dan rehabilitasi lahan pasca-tambang batubara di Indonesia Table 1. Regulations related to post coal mining reclamation and rehabilitation in Indonesia

\begin{tabular}{|c|c|c|c|}
\hline $\begin{array}{l}\text { Jenis } \\
\text { Peraturan } \\
\text { (Types of } \\
\text { regulation }\end{array}$ & $\begin{array}{l}\text { Peruntukan } \\
\text { Kawasan } \\
\text { (Purpose of } \\
\text { Area) }\end{array}$ & $\begin{array}{l}\text { Kementerian Kehutanan } \\
\text { (Ministry of Forestry) }\end{array}$ & $\begin{array}{c}\text { Kementerian ESDM } \\
\text { (Ministry of Energy and Mineral } \\
\text { Resources) }\end{array}$ \\
\hline $\begin{array}{l}\text { Undang-undang } \\
(\text { Act })\end{array}$ & Seluruh kawasan & $\begin{array}{l}\text { Undang-Undang (UU) Nomor } 41 \\
\text { Tahun } 1999 \text { tentang Kehutanan }\end{array}$ & $\begin{array}{l}\text { UU Nomor } 4 \text { Tahun } 2009 \text { tentang } \\
\text { Pertambangan Mineral dan Batubara }\end{array}$ \\
\hline \multirow{2}{*}{$\begin{array}{l}\text { Peraturan } \\
\text { Pemerintah } \\
\text { (Government } \\
\text { Regulation) }\end{array}$} & Seluruh kawasan & $\begin{array}{l}\text { Peraturan Pemerintah (PP) Nomor } 76 \\
\text { Tahun } 2008 \text { tentang Rehabilitasi dan } \\
\text { Reklamasi Hutan }\end{array}$ & $\begin{array}{l}\text { PP Nomor } 78 \text { Tahun } 2010 \text { tentang } \\
\text { Reklamasi dan Pasca-tambang }\end{array}$ \\
\hline & Seluruh kawasan & $\begin{array}{l}\text { PP Nomor } 105 \text { Tahun } 2015 \text { tentang } \\
\text { Perubahan Kedua atas PP Nomor } \\
24 \text { Tahun } 2010 \text { tentang Penggunaan } \\
\text { Kawasan Hutan }\end{array}$ & \\
\hline $\begin{array}{l}\text { Peraturan } \\
\text { Presiden } \\
\text { (Presidential } \\
\text { Decree) }\end{array}$ & Kawasan Hutan & $\begin{array}{l}\text { Peraturan Presiden (Perpres) Nomor } \\
28 \text { Tahun } 2011 \text { tentang Penggunaan } \\
\text { Kawasan Hutan Lindung untuk } \\
\text { Penambangan Bawah Tanah }\end{array}$ & \\
\hline \multirow[t]{6}{*}{$\begin{array}{l}\text { Peraturan } \\
\text { Menteri } \\
\text { (Ministerial } \\
\text { Decree) }\end{array}$} & Seluruh kawasan & & $\begin{array}{l}\text { Permen ESDM Nomor } 7 \text { Tahun } 2014 \\
\text { tentang Pelaksanaan Reklamasi dan } \\
\text { Pasca-tambang pada Kegiatan Usaha } \\
\text { Pertambangan Mineral dan Batubara }\end{array}$ \\
\hline & Kawasan Hutan & $\begin{array}{l}\text { Permen LHK Nomor P.50/Menlhk/ } \\
\text { Setjen/Kum.1/6/ } 2016 \text { tentang } \\
\text { Pedoman Pinjam Pakai Kawasan } \\
\text { Hutan }\end{array}$ & \\
\hline & Kawasan Hutan & $\begin{array}{l}\text { Permenhut Nomor P.84/Menhut- } \\
\text { II/2014 perubahan atas Permenhut } \\
\text { Nomor P.56/Menhut-II/2008 tentang } \\
\text { Tata Cara Penentuan Luas Areal } \\
\text { Terganggu dan Areal Reklamasi } \\
\text { dan Revegetasi untuk Perhitungan } \\
\text { Penerimaan Negara Bukan Pajak } \\
\text { Penggunaan Kawasan Hutan }\end{array}$ & \\
\hline & Kawasan Hutan & $\begin{array}{l}\text { Permenhut Nomor P.4/Menhut- } \\
\text { II/2011 tentang Pedoman Reklamasi } \\
\text { Hutan }\end{array}$ & \\
\hline & Kawasan Hutan & $\begin{array}{l}\text { Permen LHK Nomor P.89/MenLHK/ } \\
\text { Setjen/Kum.1/11/2016 tentang } \\
\text { Pedoman Penanaman Bagi Pemegang } \\
\text { Izin Pinjam Pakai Kawasan Hutan } \\
\text { dalam Rangka Rehabilitasi DAS }\end{array}$ & \\
\hline & Kawasan Hutan & $\begin{array}{l}\text { Permenhut Nomor P.60/Menhut- } \\
\text { II/2009 tentang Pedoman } \\
\text { Keberhasilan Reklamasi Hutan }\end{array}$ & \\
\hline
\end{tabular}

Sumber (Source) : Kementerian Hukum dan Hak Asasi Manusia Republik Indonesia, 2017.

pasca-tambang (García \& Martínez, 2012; Mc Donald et al., 2016; Rodrigues et al., 2011), khususnya yang berada di dalam kawasan hutan. Pemulihan keanekaragaman hayatiflora misalnya dapat diukur dengan menggunakan kriteria komposisi jenis (kekayaan jenis, kelimpahan jenis, keanekaragaman jenis) dan struktur vegetasi (luas dan lapisan tajuk serta distribusi diameter pohon).

Kriteria restorasi ekologi yang lain yaitu penggunaan tanaman lokal, merupakan salah satu indikator kegiatan restorasi lahan pasca- 
Tabel 2. Pedoman penilaian reklamasi hutan pada Permenhut Nomor P.60/Menhut-II/2009

Table 2. Guidance for forest reclamation evaluation in Ministerial Regulation of Forestry (Permenhut Nomor P.60/ Menhut-II/2009

\begin{tabular}{|c|c|c|c|c|c|}
\hline \multicolumn{2}{|c|}{ Penataan Lahan (Area setup) } & \multicolumn{2}{|c|}{$\begin{array}{c}\text { Pengendalian Erosi dan } \\
\text { Sedimentasi (Sedimentation and } \\
\text { erotion control) }\end{array}$} & \multicolumn{2}{|c|}{ Revegetasi (Revegetation) } \\
\hline Kegiatan (Activities) & $\begin{array}{l}\text { Bobot } \\
\text { (score) }\end{array}$ & Kegiatan (Activities) & $\begin{array}{l}\text { Bobot } \\
\text { (score) }\end{array}$ & Kegiatan (Activities) & $\begin{array}{l}\text { Bobot } \\
\text { (score) }\end{array}$ \\
\hline $\begin{array}{l}\text { Pengisian kembali } \\
\text { lubang tambang }\end{array}$ & $7,5 \%$ & $\begin{array}{l}\text { Bangunan konservasi } \\
\text { tanah } \\
\text { - Jumlah fisik bangunan } \\
\text { - Manfaat bangunan }\end{array}$ & $\begin{array}{l}5 \% \\
5 \%\end{array}$ & Luas areal penanaman & $10 \%$ \\
\hline $\begin{array}{l}\text { Luas areal yang } \\
\text { ditata }\end{array}$ & $7,5 \%$ & Penanaman cover crop & $5 \%$ & Persentase tumbuh & $10 \%$ \\
\hline Kestabilan Lahan & $7,5 \%$ & Erosi dan sedimentasi & $5 \%$ & Jumlah tanaman & $10 \%$ \\
\hline \multirow[t]{2}{*}{$\begin{array}{l}\text { Penaburan tanah } \\
\text { pucuk }\end{array}$} & $7,5 \%$ & & & $\begin{array}{l}\text { Komposisi jenis tanaman } \\
\text { (cepat tumbuh, lokal daur } \\
\text { panjang, eksotik, MPTS) }\end{array}$ & $10 \%$ \\
\hline & & & & Kesehatan tanaman & $10 \%$ \\
\hline Total & $30 \%$ & & $20 \%$ & & $50 \%$ \\
\hline
\end{tabular}

Sumber (Source): Permenhut Nomor P.60/Menhut-II/2009.

tambang (Mc Donald et al., 2016). Yassir and Omon (2009) dari hasil penelitiannya menyebutkan bahwa penggunaan jenis-jenis lokal pada kegiatan rehabilitasi tambang batubara akan membawa dampak positif bagi kegiatan konservasi keanekaragaman hayati karena jenis-jenis tersebut akan membantu mempercepat proses suksesi alami. Selain itu, penggunaan jenis lokal pada kegiatan rehabilitasi lahan juga akan menjaga keutuhan genetik jenis-jenis tersebut serta meningkatkan keberhasilan penanaman karena jenis tersebut relatif lebih adaptif terhadap lingkungan setempat.

Sebaliknya, untuk mendukung kegiatan restorasi lahan, penanaman tanaman eksotik yang bersifat invasif sebaiknya dilarang karena tanaman tersebut akan menekan pertumbuhan dan penyebaran tanaman lokal yang mengancam keberhasilan program rehabilitasi atau reklamasi (Jordan, Larson, \& Huerd, 2008; Norton, 2009; Pejchar \& Mooney, 2009; Vilà, 2011). Oleh karena itu, pelarangan penggunaan tanaman eksotik yang bersifat invasif sangat penting untuk diatur oleh pemerintah dalam bentuk regulasi sebagai upaya pencegahan potensi kegagalan program rehabilitasi atau reklamasi khususnya yang berada di dalam kawasan hutan.

Monitoring dan evaluasi (monev) juga merupakan faktor yang sangat memengaruhi keberhasilan program restorasi lahan pascatambang batubara. Hal ini karena dari kegiatan monev faktor-faktor yang memengaruhi keberhasilan ataupun kegagalan suatu program restorasi bisa dipelajari (Bernhardt et al., 2007; Kondolf et al., 2007; Lovett et al., 2007; Morandi, Piégay, Lamouroux, \& Vaudor, 2014). Meskipun demikian, kegiatan monev untuk program pemulihan dan perbaikan lahan pasca-tambang sangat jarang dilakukan karena kriteria kesuksesan suatu program restorasi sulit diprediksi (Suding, 2011). Dalam penelitian ini, regulasi-regulasi yang ada (Permen ESDM Nomor 7 Tahun 2014, Permenhut Nomor P.60/MenhutII/2009 dan Permenhut Nomor P.4/MenhutII/2011) akan ditelaah dengan metode analisis isi, apakah sudah memuat aturan atau perintah yang mewajibkan pihak perusahaan tambang 
Tabel 3. Pedoman penilaian reklamasi tahap produksi pada Peraturan Menteri ESDM Nomor 7 Tahun 2014 Table 3. Guidance for reclamation evaluation at production phase in Ministrial Regulation of Energy and Mineral Resources (Peraturan Menteri ESDM Nomor7 Tahun 2014)

\begin{tabular}{|c|c|c|c|c|c|}
\hline \multicolumn{2}{|c|}{ Penatagunaan Lahan (Land use) } & \multicolumn{2}{|c|}{ Revegetasi (Revegetation) } & \multicolumn{2}{|c|}{$\begin{array}{c}\text { Penyelesaian Akhir } \\
\text { (Finishing) }\end{array}$} \\
\hline $\begin{array}{l}\text { Kegiatan } \\
\text { (Activities) }\end{array}$ & $\begin{array}{l}\text { Bobot } \\
\text { (score) }\end{array}$ & $\begin{array}{l}\text { Kegiatan } \\
\text { (Activities) }\end{array}$ & $\begin{array}{l}\text { Bobot } \\
\text { (score) }\end{array}$ & $\begin{array}{l}\text { Kegiatan } \\
\text { (Activities) }\end{array}$ & $\begin{array}{l}\text { Bobot } \\
\text { (score) }\end{array}$ \\
\hline $\begin{array}{l}\text { Penataan permukaan tanah } \\
\text { dan penimbunan kembali } \\
\text { lahan pasca-tambang }\end{array}$ & $40 \%$ & $\begin{array}{l}\text { Penanaman tanaman penutup } \\
\text { (cover crop) }\end{array}$ & $2,5 \%$ & Penutupan tajuk & $10 \%$ \\
\hline $\begin{array}{l}\text { Penyebaran tanah zona } \\
\text { pengakaran }\end{array}$ & $10 \%$ & $\begin{array}{l}\text { Penanaman tanaman cepat } \\
\text { tumbuh }\end{array}$ & $7,5 \%$ & $\begin{array}{l}\text { Pemeliharaan/ } \\
\text { Perawatan } \\
\text { Tanamam }\end{array}$ & $10 \%$ \\
\hline \multirow[t]{2}{*}{$\begin{array}{l}\text { Pengendalian erosi dan } \\
\text { pengelolaan air }\end{array}$} & $10 \%$ & $\begin{array}{l}\text { Penanaman tanaman jenis } \\
\text { lokal }\end{array}$ & $5 \%$ & & \\
\hline & & $\begin{array}{l}\text { Pengendalian air asam } \\
\text { tambang }\end{array}$ & $5 \%$ & & \\
\hline Total & $60 \%$ & & $20 \%$ & & $20 \%$ \\
\hline
\end{tabular}

Sumber (Source): Peraturan Menteri Energi Sumber Daya Mineral Nomor 7 Tahun 2014.

untuk melakukan kegiatan monev. Selain itu, apakah sistem monev yang diamanatkan dalam regulasi tersebut sudah efektif untuk menunjang keberhasilan perbaikan dan pemulihan lahan pasca-tambang batubara.

Permenhut Nomor P.60/Menhut-II/2009 tentang Pedoman Keberhasilan Reklamasi Hutan menyebutkan kriteria keberhasilan reklamasi hutan secara garis besar yang terdiri dari 3 (tiga) aspek yaitu penataan lahan, pengendalian erosi dan sedimentasi, serta revegetasi. Pada Permen ESDM Nomor 7 Tahun 2014, peraturan tersebut menyebutkan bahwa kriteria keberhasilan reklamasi baik tahap eksplorasi dan eksploitasi secara garis besar juga terdiri dari 3 (tiga) aspek yaitu penatagunaan lahan, revegetasi dan penyelesaiaan akhir. Secara ringkas, kriteria, kegiatan dan bobot untuk kedua peraturan tersebut masing-masing tersaji pada Tabel 2 dan Tabel 3.

Berdasarkan kriteria penilaian keberhasilan kegiatan reklamasi pasca-tambang seperti yang disajikan dalam Tabel 2 dan Tabel 3, kemudian dikaji apakah pedoman reklamasi dan pedoman penilaian keberhasilan reklamasi pasca-tambang yang telah diatur pada ketiga peraturan menteri tersebut telah sesuai dan memenuhi 5 (lima) kriteria restorasi ekologi, yaitu pemulihan keanekaragaman hayati, remediasi tanah, penggunaan tanaman lokal, pelarangan penggunaan tanaman invasif, serta monitoring dan evaluasi kegiatan.

\section{HASIL DAN PEMBAHASAN}

\section{A. Indikator Penilaian Keberhasilan Reklamasi berdasarkan Kriteria Restorasi Ekologi dalam Perundang- undangan di Indonesia}

Hasil kajian menunjukkan bahwa peraturan yang ada saat ini belum seluruhnya memenuhi prinsip dan indikator dari restorasi ekologi (Tabel 4). Namun demikian sebenarnya ketiga peraturan tersebut sudah cukup baik dan dapat saling melengkapi untuk memenuhi kriteria dan indikator restorasi ekologi. Berdasarkan Tabel 4 menunjukkan pula bahwa meski peraturan tersebut dapat saling melengkapi, namun khusus untuk kriteria dan indikator pemulihan keanekaragaman hayati dan pelarangan penggunaan jenis tanaman eksotik invasif peraturan yang ada masih belum mengatur secara jelas dan lengkap. Terkait 


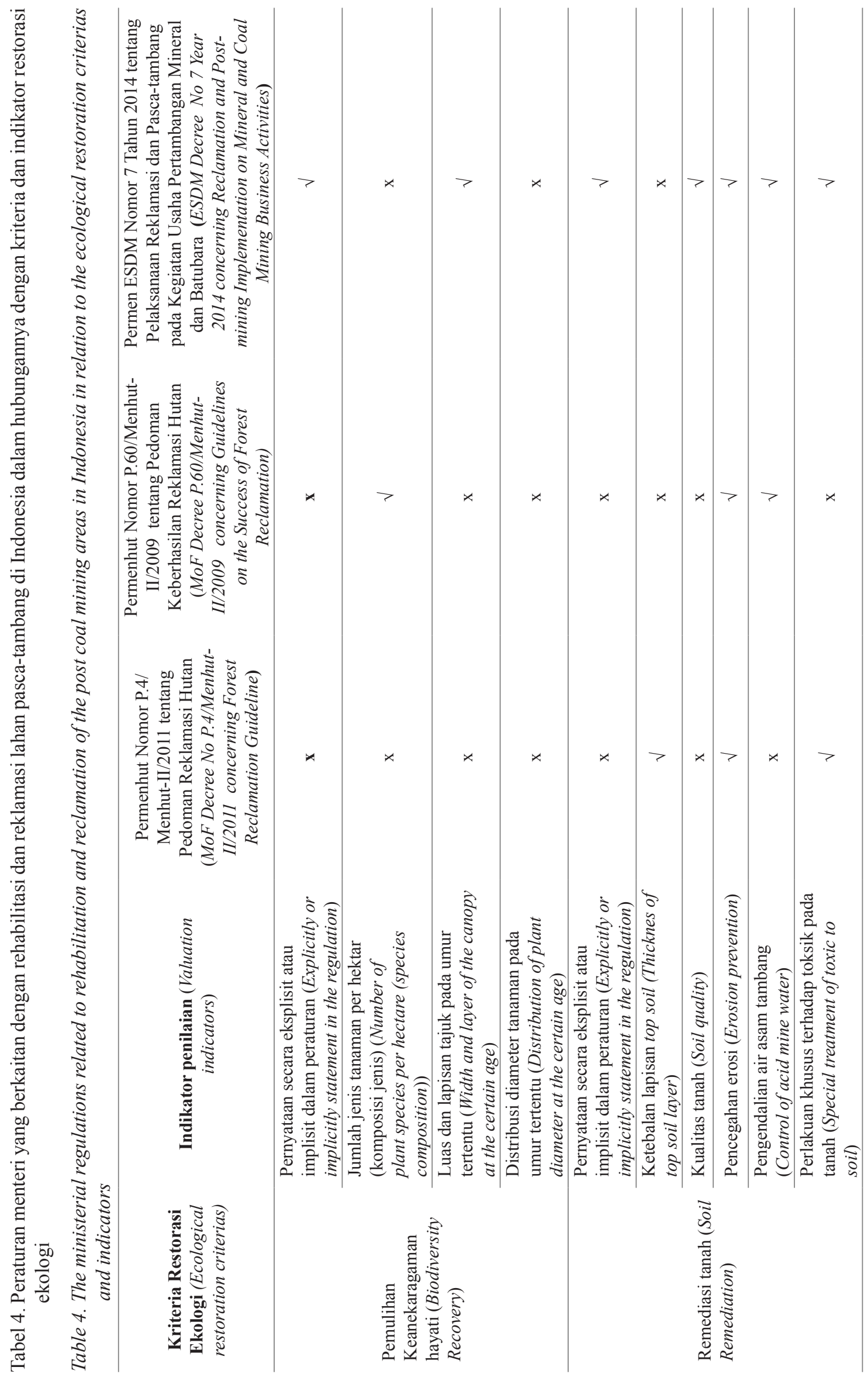




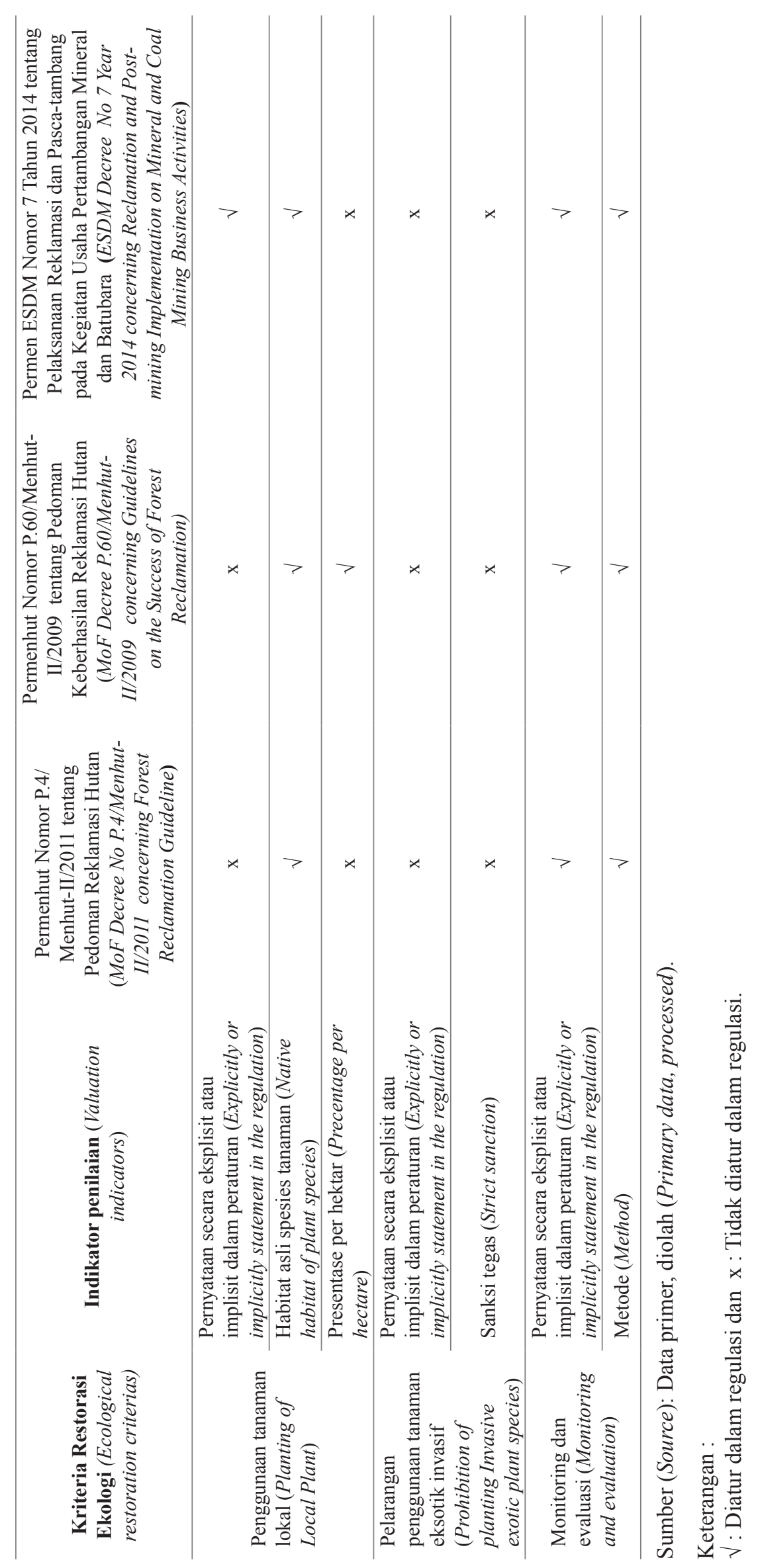


dengan kriteria dan indikator pemulihan keanekaragaman hayati dan pelarangan penggunaan jenis tanaman eksotik invasif dalam konsep restorasi ekologi, kedua hal tersebut menjadi sangat penting khususnya dalam rangka pengaturan kegiatan reklamasi dan revegetasi di dalam kawasan hutan dengan skema IPPKH.

Selain itu, berdasarkan Tabel 4 dapat diketahui secara jelas pula bahwa diperlukan sinkronisasi peraturan-peraturan baik peraturan yang dikeluarkan oleh Kementerian ESDM dan Kementerian LHK. Hal ini menjadi penting karena meski peraturan Kementerian LHK khusus mengatur kegiatan reklamasi dan revegetasi di dalam kawasan hutan dengan skema IPPKH, namun peraturan yang dikeluarkan oleh Kementerian ESDM tidak hanya mengatur dan berlaku di dalam kawasan APL saja, tetapi juga di dalam kawasan hutan. Berikut penjelasan berdasarkan Tabel 4 terkait peraturan yang mengatur kegiatan reklamasi dan revegetasi dalam pemenuhan konsep restorasi ekologi.

\section{Pemulihan Keanekaragaman Hayati}

Pemulihan keanekaragaman hayati sebagai tujuan kegiatan rehabilitasi dan reklamasi lahan pasca-tambang secara tegas disebutkan hanya pada Peraturan Pemerintah (PP) Nomor 78 Tahun 2010 dan Peraturan Menteri ESDM Nomor 7 Tahun 2014, sedangkan peraturan yang dikeluarkan oleh Kementerian LHK baik Permenhut Nomor P.60/Menhut-II/2009 dan Permenhut Nomor P.4/Menhut-II/2011 tidak secara tegas menyebutkan pemulihan keanekaragaman hayati sebagai tujuan kegiatan rehabilitasi dan reklamasi lahan pasca-tambang di kawasan hutan dengan skema IPPKH. Khusus pada PP Nomor 78 Tahun 2010 pasal 4 ayat 1 b menyatakan bahwa perlindungan dan pemulihan keanekaragaman hayati merupakan salah satu prinsip dari perlindungan dan pengelolaan lingkungan hidup pertambangan, sedangkan pada Peraturan Menteri ESDM Nomor 7 Tahun 2014, pasal 2 ayat 3 menyatakan prinsip yang sama dengan PP Nomor 78 Tahun 2010 di atas. Sebaliknya, baik dalam Permenhut Nomor P.60/Menhut-II/2009 dan Permenhut Nomor P.4/Menhut-II/2011 tidak secara tegas menyebutkan seperti yang disebutkan di PP Nomor 78 Tahun 2010 tentang tentang Reklamasi dan Pascatambang dan Peraturan Menteri ESDM Nomor 7 Tahun 2014.

Namun, berdasarkan indikator penilaian dan kriteria pemulihan keanekaragaman hayati baik peraturan yang dikeluarkan oleh Kementerian ESDM dan Kementerian LHK sebenarnya dapat saling melengkapi. Sebagai contoh, Peraturan Menteri ESDM Nonor 7 Tahun 2014 telah mengatur luas tutupan tajuk dalam pedoman penilaian keberhasilan reklamasi dan revegetasi, tetapi tidak mengatur komposisi jenis atau jumlah jenis tanaman per hektar. Sebaliknya Permenhut Nomor P.60/Menhut-II/2009 telah mengatur komposisi jenis per hektar, tetapi tidak mengatur luas tutupan tajuk dalam pedoman penilaian keberhasilan reklamasi dan revegetasi. Meskipun demikian, baik peraturan yang dikeluarkan oleh Kementerian ESDM dan Kementerian LHK masih belum memasukan distribusi diameter tanaman pada umur tertentu dalam pedoman penilaian keberhasilan reklamasi dan revegetasi lahan pasca-tambang. Padahal, informasi distribusi diameter tanaman juga penting terkait dengan pemulihan keanekaragaman hayati karena tidak hanya dapat memberikan informasi atau petunjuk bahwa permudaan alami di lokasi yang sedang dilakukan reklamasi dan revegetasi telah berjalan dengan baik atau tidak, namun juga memberikan informasi terkait produktivitas dari kondisi lahan yang sedang direklamasi dan revegetasi seperti apakah sebaran diameter baik pada tingkat pohon, tiang dan pancang serta semai telah proporsional mengikuti pola tertentu sesuai dengan karakteristiknya.

\section{Remediasi Tanah}

Berdasarkan Tabel 4 menunjukkan bahwa baik peraturan yang dikeluarkan oleh 
Kementerian ESDM dan Kementerian LHK yaitu dalam Peraturan Menteri ESDM Nomor 7 Tahun 2014 dan Permenhut Nomor P.4/ Menhut-II/2011 telah memuat remediasi tanah sebagai salah satu indikator di dalam menilai keberhasilan reklamasi dan revegetasi lahan pasca-tambang dan dapat saling melengkapi. Khusus pada Peraturan Menteri ESDM Nomor 7 Tahun 2014 kewajiban remediasi tanah terdapat pada pasal 16 yaitu pada bagian ketiga penyusunan rencana pascatambang. Mengacu pada pasal tersebut maka disebutkan bahwa biaya remediasi tanah harus dimasukkan dalam anggaran kegiatan pasca-tambang untuk memulihkan tanah yang terkontaminasi. Kemudian pada Lampiran III Peraturan Menteri ESDM Nomor 7 Tahun 2014, dijelaskan bahwa kontaminasi yang dimaksud adalah kontaminasi bahan kimia, minyak serta bahan berbahaya dan beracun atau limbah bahan berbahaya dan beracun.

Dalam Permenhut Nomor P.4/MenhutII/2011 kewajiban remediasi tanah secara tidak langsung disebutkan dalam "pengelolaan tanah pucuk" yang terdapat pada beberapa pasal seperti pada pasal 15, 17, 19, 30, 32, 38 dan 39. Khusus pada pasal 38, dijelaskan secara detail tentang pengelolaan tanah pucuk, dimana pada ayat 2 disebutkan bahwa tanah pucuk merupakan media tumbuh bagi tanaman dan merupakan salah satu faktor penentu untuk keberhasilan pertumbuhan tanaman pada kegiatan reklamasi. Kemudian pada pasal 39 ayat $1 \mathrm{~d}$ dijelaskan pula bahwa tanah yang mengandung racun harus ditimbun dengan tanah pucuk lebih tebal dari pada tanah yang tidak beracun, atau diberi perlakuan secara khusus dengan cara mengisolasi dan memisahkannya.

\section{Penggunaan Tanaman Jenis Lokal}

Penggunaan tanaman jenis lokal pada kegiatan rehabilitasi dan reklamasi secara tegas diatur pada PP Nomor 76 Tahun 2008 pada pasal 35 ayat 3. Pada pasal dan ayat tersebut menyebutkan bahwa rehabilitasi pada kawasan konservasi harus dilakukan dengan menanam tumbuhan asli setempat. Hal ini berarti tanaman eksotik termasuk yang bersifat invasif dengan tegas dilarang digunakan untuk rehabilitasi kawasan hutan konservasi. Akan tetapi, izin konsesi pertambangan tidak diperbolehkan pada kawasan konservasi, sedangkan pada kawasan hutan produksi dan hutan lindung, pada pasal 36 ayat 3 disebutkan bahwa dihindari sejauh mungkin penggunaan tumbuhan eksotis atau jenis tumbuhan asing dalam kegiatan rehabilitasi di kawasan tersebut. Oleh karena itu, berdasarkan peraturan tersebut maka penggunaan jenis tanaman eksotik masih memungkinkan untuk digunakan pada kegiatan rehabilitasi pada kawasan hutan produksi dan hutan lindung. Maka, perubahan struktur komposisi jenis kawasan hutan pasca-tambang sangat mungkin terjadi pada kawasan tersebut.

Khusus peraturan yang dikeluarkan oleh Kementerian LHK penggunaan tanaman jenis lokal di dalam kegiatan reklamasi pasca-tambang juga telah diatur baik di dalam Permenhut Nomor P.60/MenhutII/2009 dan Permenhut Nomor P.4/MenhutII/2011. Khusus pada Permenhut Nomor P.4/ Menhut-II/2011 penggunaan tanaman jenis lokal diatur pada pasal 23, 50 dan 51, dimana secara umum dijelaskan bahwa penggunaan jenis lokal ditujukan untuk pengkayaan jenis dimana pelaksanaannya secara teknis dilakukan setelah beberapa tahun dari kegiatan reklamasi dan revegetasi, sedangkan pada Permenhut Nomor P.60/Menhut-II/2009 juga telah mengatur dimana penggunaan jenis tanaman lokal merupakan salah satu indikator yang dipergunakan di dalam menilai keberhasilan kegiatan reklamasi hutan pascatambang. Mengacu Permenhut Nomor P.60/ Menhut-II/2009 penggunaan jenis lokal diatur dalam komposisi jenis dimana dijelaskan bahwa penggunaan jenis lokal disarankan minimal $40 \%$ terhadap jumlah pohon yang ditanam per hektarnya. Khusus peraturan yang dikeluarkan oleh Kementerian ESDM, penggunaan jenis lokal juga telah diatur dalam Peraturan Menteri ESDM Nomor 7 
Tahun 2014 pada pasal 53.

Pada pasal 53 tersebut dijelaskan bahwa tanaman jenis lokal merupakan bagian dari program revegetasi pasca-tambang, yaitu pada saat pencairan dana jaminan reklamasi sebesar $80 \%$. Lebih detail pada pedoman penilaian reklamasi tahap operasi produksi, pada Lampiran XI Peraturan Menteri ESDM Nomor 7 Tahun 2014 disebutkan bahwa penanaman jenis lokal mempunyai bobot $5 \%$ dari total $80 \%$ tersebut, $20 \%$ sisanya adalah penutupan tajuk dan perawatan. Mengacu pada Tabel 2 meskipun peraturan baik yang dikeluarkan oleh Kementerian ESDM maupun Kementerian LHK sudah mengatur penggunaan tanaman jenis lokal namun bobot nilainya sangat kecil di dalam penentu keberhasilan dari kegiatan reklamasi dan revegetasi lahan pasca-tambang. Padahal penggunaan jenis tanaman lokal menjadi penting khususnya di dalam kegiatan reklamasi dan revegetasi lahan pasca-tambang khususnya yang berada di dalam kawasan hutan dengan skema IPPKH. Ke depan, selain diperlukan sinkronisasi untuk saling melengkapi, juga diperlukan penambahan bobot di dalam penentuan keberhasilan dari kegiatan reklamasi dan revegetasi lahan pasca-tambang khususnya yang berada di dalam kawasan hutan dengan skema IPPKH.

\section{Pelarangan Penggunaan Jenis-jenis Tanaman Eksotik Invasif}

Berdasarkan Tabel 4 dapat diketahui bahwa baik Peraturan Menteri ESDM Nomor 7 Tahun 2014 dan Permenhut Nomor P.60/ Menhut-II/2009 dan Permenhut Nomor P.4/Menhut-II/2011 tidak satupun dari peraturan tersebut yang melarang dengan tegas penggunaan tanaman eksotik invasif dalam kegiatan rehabilitasi dan reklamasi lahan pasca-tambang batubara. Pelarangan penggunaan jenis-jenis tanaman eksotik yang bersifat invasif dalam kegiatan reklamasi dan revegetasi lahan pasca-tambang khususnya yang berada di dalam kawasan hutan ke depannya harus segera diatur oleh pemerintah.
Hal ini dikarenakan selain untuk mencegah terjadinya perubahan struktur dan komposisi jenis, juga dalam rangka menjaga keutuhan genetik jenis-jenis lokal setempat.

\section{Monitoring dan Evaluasi}

Dari Tabel 2 diatas dapat diketahui bahwa ketigaperaturan baik Peraturan Menteri ESDM Nomor 7 Tahun 2014, Permenhut Nomor P.60/ Menhut-II/2009, dan Permenhut Nomor P.4/ Menhut-II/2011 telah menyatakan kewajiban pemegang konsesi pertambangan batubara untuk melakukan kegiatan monitoring dan evaluasi pasca-tambang. Pada ketiga peraturan tersebut juga telah disertakan metode untuk melakukan kegiatan monitoring dan evaluasi secara detail pada bagian lampiran. Pada Peraturan Menteri ESDM Nomor 7 Tahun 2014, kewajiban melakukan monitoring dan evaluasi dilakukan sebagai syarat pencairan dana jaminan reklamasi, yang dijelaskan pada pasal 46, 51, 57 dan 60-62. Pada peraturan lain, Peraturan Menteri Kehutanan Permenhut Nomor P.4/Menhut-II/2011, pada pasal 69 dijelaskan bahwa kegiatan evaluasi terhadap pelaksanaan reklamasi dilakukan setiap 5 (lima) tahun sekali atau setahun sebelum berakhirnya masa berlaku izin pinjam pakai kawasan hutan. Untuk Permenhut Nomor P.60/Menhut-II/2009 peraturan tersebut merupakan pedoman evaluasi atau penilaian keberhasilan reklamasi hutan itu sendiri.

\section{B. Terminologi Jenis Lokal, Endemik dan Jenis Asli Setempat}

Secara teknis, dalam implementasi peraturan yang ada terkait kegiatan reklamasi dan revegetasi lahan pasca-tambang, terdapat potensi permasalahan dalam terminologi 'tumbuhan jenis lokal', 'endemik' dan 'jenis asli setempat'. Perbedaan terminologi akan mengakibatkan perbedaan interpretasi saat implementasi di lapangan sehingga tujuan yang akan dikehendaki menjadi tidak tercapai. Tanaman 'asli setempat' atau dalam bahasa Inggris disebut native species, mempunyai dua makna lain yaitu endemik dan indigenous, 
masing-masing istilah tersebut mempunyai definisi mirip, namun tidak sepenuhnya sama sehingga mempunyai implikasi yang berbeda ketika diaplikasikan di lapangan. Definisi spesies endemik dari The IUCN Red List of Threatened Species (2016) adalah spesies asli (native) yang tinggal pada suatu wilayah geografis tertentu. Artinya, jenis tersebut hanya ada di satu tempat saja dan tidak ditemukan ditempat lain.

Lain halnya dengan definisi spesies indigenous, menurut The IUCN Red List of Threatened Species (2016), merupakan suatu spesies bagian dari suatu ekosistem yang telah ada dan berkembang dalam periode yang lama secara alami tanpa bantuan manusia. Berdasarkan pengertian tersebut, artinya spesies tersebut hidup di satu tempat tetapi masih dapat ditemukan di tempat lain karena berpindah secara alami. Kesulitan yang mungkin akan terjadi dalam kegiatan rehabilitasi adalah ketika jenis tanaman endemik digantikan jenis indigenous sehingga mengancam eksistensi spesies endemik tersebut karena terjadi pengurangan luasan habitat jenis endemik tersebut. Meskipun secara legal hal tersebut dapat dibenarkan, akan tetapi hal tersebut akan berdampak negatif terhadap konservasi jenis-jenis tumbuhan endemik.

\section{Jenis Tumbuhan Eksotik dan Eksotik Invasif}

Berdasarkan peraturan yang ada, tidak adanya pelarangan penggunaan jenis tanaman eksotik invasif dalam kegiatan rehabilitasi lahan pasca-tambang dapat berakibat negatif terhadap upaya pemulihan dan perbaikan di dalam sebuah ekosistem yang terganggu. Dampak negatif dan gangguan tersebut tidak hanya akan dapat merubah arah dari proses suksesi alami yang sedang berlangsung, tetapi juga berpotensi merubah struktur dan komposisi jenis di ekosistem tersebut. Hal ini berarti bahwa dengan tidak adanya pelarangan penggunaan jenis tanaman eksotik invasif khususnya di dalam kegiatan reklamasi dan revegetasi lahan pasca-tambang di kawasan hutan akan berimplikasi bahwa struktur dan komposisi jenis dari ekosistem hutan yang akan dihasilkan akan jauh berbeda dengan sebelumnya.

Beberapa penelitian telah mengkonfirmasi dampak negatif penggunaan jenis tumbuhan eksotik invasif dalam kegiatan rehabilitasi lahan pasca-tambang. Hobbs, Higgs, and Harris (2009), melaporkan bahwa kegiatan restorasi ekologi di Southwestern Australian Woodlands menjadi sangat sulit dilakukan karena invasi spesies eksotik yang telah merubah struktur kimia dan fisik tanah sehingga spesies endemik kesulitan untuk tumbuh kembali. Kemudian Le Maitre et al. (2011) melaporkan bahwa beberapa jenis tumbuhan Acacia sp. dari Australia telah menginvasi beberapa negara lain seperti; Acacia dealbata di Chile, A. longifolia di Portugal dan A. saligna di Afrika Selatan. Jenis-jenis tersebut menjadi dominan setelah biji-bijinya terakumulasi secara masif di dalam tanah dan tumbuh setelah gangguan. Pada penelitian lain, Marchante, Kjøller, Struwe, and Freitas (2009) melaporkan bahwa invasi $A$. longifolia telah menyebabkan adanya perubahan signifikan pada kandungan $\mathrm{C}$ dan $\mathrm{N}$ pada tanah, dibandingkan dengan daerah yang tidak ter-invasi, kandungan $\mathrm{C}$ dan $\mathrm{N}$ diperkirakan mencapai 50-80\% lebih tinggi. Menurut penelitian tersebut, tingginya kandungan $\mathrm{C}$ dan $\mathrm{N}$ dalam tanah akan memberikan kondisi yang tepat bagi $A$. longifolia untuk mendominasi ruang tumbuh dan menghambat jenis lain untuk tumbuh di tempat yang sama, Oleh karena itu, hasil akhir kegiatan rehabilitasi lahan pasca-tambang akan berbeda dengan kondisi awal terutama dalam hal struktur dan komposisi vegetasi meskipun mungkin dapat memiliki fungsi kawasan yang sama untuk dampak yang terkecil.

Namun demikian, terdapat pula pendapat lain yang menyatakan bahwa spesies eksotis diperlukan dalam kegiatan restorasi lahan terdegradasi yang cukup berat seperti lahan 
pasca-tambang batubara. Selain itu, kajian yang dilakukan oleh Schlaepfer, Sax, \& Olden (2011) menyebutkan bahwa terdapat berbagai manfaat penggunaan tanaman non-native untuk spesies native, diantaranya; sebagai penyedia ruang tumbuh layak (shelter) bagi spesies native; sebagai perekayasa ekosistem (ecosystem engineers) untuk spesies native; dan sebagai katalisator untuk restorasi ekosistem.

Berdasarkan penjelasan yang ada baik yang bersifat pro dan kontra di dalam penggunaan jenis eksotik, maka prioritas penggunaan jenis-jenis eksotik harus diminimalkan dan pemilihan jenis eksotik tersebut juga sedemikian rupa menghindari jenis-jenis eksotik yang bersifat invasif. Hal ini menjadi penting untuk dilakukan mengingat beberapa jenis eksotik juga memiliki kemampuan yang baik di dalam pertumbuhannya sehingga mampu mempercepat perbaikan iklim mikro. Selain itu, Chazdon (2008) juga mengatakan bahwa dalam kegiatan restorasi hutan, ekosistem hutan harus tahan terhadap berbagai tekanan seperti perubahan iklim, fragmentasi habitat dan tekanan akibat aktivitas manusia lainnya sehingga pengelolaan hutan yang bersifat adaptif juga diperlukan.

\section{Kegiatan Rehabilitasi dan Reklamasi dalam Hubungannya dengan Status Kawasan}

Berdasarkan peraturan yang ada, izin konsesi tambang hanya diberikan pada lahan dengan status kawasan hutan produksi (HP), hutan lindung (HL) dan Areal Penggunaan Lain (APL). Kawasan konservasi tidak diperbolehkan untuk diberikan izin untuk ditambang. Khusus untuk kawasan hutan lindung, penambangan juga harus dilakukan dengan sistem tertutup atau bawah tanah. Di lain pihak, tujuan dari ditetapkannya kawasan hutan produksi adalah untuk memproduksi hasil hutan. Oleh karena itu, apabila sebuah perusahaan tambang batubara berada pada kawasan hutan produksi dengan skema Izin Pinjam Pakai Kawasan Hutan (IPPKH), maka dalam kegiatan rehabilitasi lahan pascatambang boleh menggunakan jenis-jenis tanaman komersil, meskipun bukan jenis tanaman lokal setempat. Hal ini berpotensi akan merubah struktur dan komposisi jenis di kawasan hutan produksi tersebut.

Mengacu informasi dari statistik kehutanan 2015 (Ministry of Environment and Forestry, 2016), sampai dengan tahun 2015 di Indonesia terdapat total 504.300 hektar konsesi pertambangan dengan skema IPPKH baik untuk kegiatan operasi produksi tambang dan non-tambang, dan sekitar 200.424 hektar terdapat di Provinsi Kalimantan Timur. Angka tersebut belum termasuk tambang di kawasan APL, yang luasnya belum diketahui secara pasti karena perizinannya lewat pemerintah daerah sehingga data luasan tambangnya masih sulit diakses. Meskipun demikian, di Provinsi Kalimantan Timur, pada tahun 2013 terdapat 1.451 izin usaha pertambangan (IUP) batubara dengan luas total 5,3 juta hektar dan 67 perjanjian karya pengusahaan pertambangan batubara (PKP2B) dengan luas total 1,6 juta hektar (Saturi, 2013).

Berdasarkan angka yang ada misalnya IUP batubara yang berada di Provinsi Kalimantan Timur dengan luas total 5,3 juta hektar (baik eksplorasi dan produksi) tidak hanya berpotensi akan merubah struktur dan komposisi jenis pada kawasan tersebut saja, tetapi juga fungsi dari kawasan tersebut. Untuk itu, selain diperlukan perbaikan secara menyeluruh dengan prinsip kehati-hatian di dalam hal mekanisme pemberian izin bagi pemegang IUP, juga diperlukan mekanisme peraturan yang lebih tegas dan lengkap serta ringkas yang memenuhi prinsip-prinsip restorasi ekologi dalam upaya perbaikan dan pemulihan lahan-lahan pasca-tambang batubara. Selain itu, ke depannya sinkronisasi peraturan antara Kementerian ESDM maupun Kementerian LHK juga sangat penting dilakukan dalam rangka saling melengkapi dan berbagi peran dan fungsi terutama di dalam mengatur ruang lingkup kewenangan berdasarkan status kawasan. 


\section{KESIMPULAN DAN SARAN}

\section{A. Kesimpulan}

Sebagai kesimpulan, regulasi tentang reklamasi dan rehabilitasi di Indonesia tidak sepenuhnya selaras dengan konsep ekologi restorasi karena hanya memuat sebagian dari kriteria dan indikator kegiatan restorasi ekologi. Pada bagian remediasi tanah, hal tersebut sudah diatur baik oleh Kementerian ESDM dan Kementerian LHK, sedangkan prinsip pemulihan keanekaragaman hayati sudah diatur oleh Kementerian ESDM, tetapi tidak diatur secara tegas di dalam peraturan yang dikeluarkan oleh Kementerian LHK. Selain itu, meskipun penggunaan tanaman jenis lokal sudah terdapat pada beberapa regulasi yang dikeluarkan oleh Kementerian ESDM dan Kementerian LHK, namun tidak terlalu signifikan karena bobot nilainya yang kecil dan tidak memengaruhi hasil akhir penilaian keberhasilan rehabilitasi dan reklamasi.

Dalam hal penggunaan tanaman eksotik invasif, berdasarkan aturan yang ada, tidak satupun peraturan yang ada melarang penggunaan tanaman eksotik invasif dalam kegiatan reklamasi dan revegetasi lahan pasca-tambang batubara. Tidak adanya pelarangan ini berpotensi tidak hanya akan merubah struktur dan komposisi jenis vegetasi yang ada, tetapi juga keutuhan genetik dari tanaman lokal.

\section{B. Saran}

Sebagai saran terhadap pihak yang memformulasikan kebijakan, perbaikan terhadap Permenhut Nomor P.4/MenhutII/2011 tentang Pedoman Reklamasi Hutan dan Permenhut Nomor P.60/Menhut-II/2009 tentang Pedoman Penilaian Keberhasilan Reklamasi Hutan agar sesuai dan memenuhi prinsip-prinsip restorasi ekologi perlu dilakukan untuk mengurangi dampak negatif kegiatan tambang batubara (IUP) yang berada dalam kawasan hutan dengan skema IPPKH dan mengembalikan struktur fungsi hutan mendekati semula.

Selain itu, terminologi 'tumbuhan jenis lokal' dan 'asli setempat' dalam peraturan perundangan yang berlaku perlu diganti menjadi 'tumbuhan endemik' agar tidak menimbulkan kesulitan dalam aplikasi kegiatan reklamasi pasca-tambang batubara di lapangan. Kesulitan yang mungkin akan terjadi adalah ketika jenis tanaman endemik digantikan jenis indigenous sehingga mengancam eksistensi spesies endemik tersebut karena terjadi pengurangan luasan habitat jenis endemik tersebut.

\section{UCAPAN TERIMA KASIH (ACKNOWLEDGEMENT)}

Penulis mengucapkan terima kasih kepada pihak-pihak yang membantu dalam penelitian ini yaitu perusahaan tambang batubara bagian lingkungan PT Singlurus Pratama dan Balai Penelitian dan Pengembangan Teknologi Konservasi Sumberdaya Alam (BP2TKSDA) Samboja.

\section{DAFTAR PUSTAKA}

Ahmad, Y. (2012). Studi besarnya erosi pada areal reklamasi tambang batubara di PT Arutmin Indonesia Kabupaten Kotabaru. Jurnal Hutan Tropis Borneo, 13(1), 46-54.

Beesley, L., Moreno-Jiménez, E., Gomez-Eyles, J. L., Harris, E., Robinson, B., \& Sizmur, T. (2011). A review of biochars' potential role in the remediation, revegetation and restoration of contaminated soils. Environmental Pollution, 159(12), 3269-3282.

Bernhardt, E. S., Sudduth, E. B., Palmer, M. A., Allan, J. D., ..., \& Lave, R. (2007). Restoring rivers one reach at a time: Results from a survey of US river restoration practitioners. Restoration Ecology, 15(3), 482-493.

Bott, T. L., Jackson, J. K., McTammany, M. E., ...., \& Battle, J. M. (2012). Abandoned coal mine drainage and its remediation: Impacts on stream ecosystem structure and function. Ecological Applications, 22(8), 2144-2163.

Chazdon, R. L. (2008). Beyond deforestation: Restoring forests and ecosystem services on degraded lands. Science, 320(5882), 14581460 . 
Crowley, B. P., \& Delfico, J. F. (1996). Content analysis: A methodology for structuring and analyzing written material. Washington DC: United States General Accounting Office (GAO), Program Evaluation and Methodology Division.

Endriantho, M., Ramli, M., Hasanuddin, T. P. U., \& Hasanuddin, T. G. U. (2013). Perencanaan sistem penyaliran tambang terbuka batubara (Open coal mining drainage system planning) Geosains, 09(01), 29-40.

García, D., \& Martínez, D. (2012). Species richness matters for the quality of ecosystem services: A test using seed dispersal by frugivorous birds. Proceedings of the Royal Society B: Biological Sciences. DOI: 10.1098/ rspb.2012.0175.

Heneghan, L., Miller, S. P., Baer, S., ....., \& Richardson, S. (2008). Integrating soil ecological knowledge into restoration management. Restoration Ecology, 16(4), 608-617.

Hobbs, R. J., Higgs, E., \& Harris, J. A. (2009). Novel ecosystems: Implications for conservation and restoration. Trends in Ecology \& Evolution, 24(11), 599-605.

Jordan, N. R., Larson, D. L., \& Huerd, S. C. (2008). Soil modification by invasive plants: Effects on native and invasive species of mixed-grass prairies. Biological Invasions, 10(2), 177-190.

Kementerian Hukum dan Hak Asasi Manusia Republik Indonesia. (2017). Database peraturan. Media publikasi peraturan perundang-undangan dan informasi hukum. Retrieved 8 November 2016 from http://ditjenpp.kemenkumham. go.id/database-peraturan/undang-undang. html.

Kondolf, G. M., Anderson, S., Lave, R., Pagano, L., Merenlender, A., \& Bernhardt, E. (2007). Two decades of river restoration in California: What can we learn? Restoration Ecology, 15(3), 516-523.

Krippendorff, K. (2004). Content analysis: An introduction to its methodology ( $2^{\text {nd }}$ Edition). Thousand Oaks, CA: Sage Publication.

Le Maitre, D. C., Gaertner, M., Marchante, E., ...., \& Blignaut, J. (2011). Impacts of invasive Australian acacias: Implications for management and restoration. Diversity and Distributions, 17(5), 1015-1029.

Lovett, G. M., Burns, D. A., Driscoll, C. T., ......., \& Haeuber, R. (2007). Who needs environmental monitoring? Frontiers in Ecology and the Environment, 5(5), 253-260.

Marchante, E., Kjøller, A., Struwe, S., \& Freitas, H. (2009). Soil recovery after removal of the N2-fixing invasive Acacia longifolia:
Consequences for ecosystem restoration. Biological Invasions, 11(4), 813-823.

Marganingrum, D., \& Noviardi, R. (2009). Pencemaran air dan tanah di kawasan pertambangan batubara di PT. Berau Coal, Kalimantan Timur. Riset Geologi dan Pertambangan, 20(1), 11-20.

McDonald, T., Gann, G., Jonson, J., \& Dixon, K. (2016). International standards for the practice of ecological restoration - Including principles and key concepts. (First Edition). Washington, DC: Society for Ecological Restoration.

Ministry of Environment and Forestry. (2016). Statistics of Ministry of Environment and Forestry 2015. Jakarta: Ministry of Environment anf Forestry.

Morandi, B., Piégay, H., Lamouroux, N., \& Vaudor, L. (2014). How is success or failure in river restoration projects evaluated? Feedback from French restoration projects. Journal of Environmental Management, 137, 178-188.

Norton, D. A. (2009). Species invasions and the limits to restoration: Learning from the New Zealand experience. Science, 325(5940), 569-571.

Pejchar, L., \& Mooney, H. A. (2009). Invasive species, ecosystem services and human well-being. Trends in Ecology \& Evolution, 24(9), 497504.

Peraturan Menteri Energi Sumber Daya Mineral Republik Indonesia Nomor 07 Tahun 2014 tentang Pelaksanaan Reklamasi dan Pascatambang pada Kegiatan Usaha Pertambangan Mineral dan Batubara.

Peraturan Menteri Kehutanan Republik Indonesia Nomor P.60/Menhut-II/2009 tentang Pedoman Penilaian Keberhasilan Reklamasi Hutan.

Peraturan Menteri Kehutanan Republik Indonesia Nomor P.4/Menhut-II/2011 tentang Pedoman Reklamasi Hutan.

Peraturan Menteri Kehutanan Nomor P.84/MenhutII/2014 perubahan atas Peraturan Menteri Kehutanan Nomor P.56/Menhut-II/2008 tentang Tata Cara Penentuan Luas Areal Terganggu dan Areal Reklamasi dan Revegetasi untuk Perhitungan Penerimaan Negara Bukan Pajak Penggunaan Kawasan Hutan/

Peraturan Menteri Lingkungan Hidup dan Kehutanan Republik Indonesia Nomor P.89/ Menlhk/ Setjen/Kum.1/11/2016 tentang Pedoman Penanaman Bagi Pemegang Izin Pinjam Pakai Kawasan Hutan dalam Rangka Rehabilitasi Daerah Aliran Sungai. 
Peraturan Menteri Lingkungan Hidup dan Kehutanan Republik Indonesia No P.50/Menlhk/Setjen/ Kum.1/6/2016 tentang Pedoman Pinjam Pakai Kawasan Hutan.

Peraturan Pemerintah Nomor 78 Tahun 2010 tentang Reklamasi dan Pasca-tambang.

Peraturan Pemerintah Nomor 76 Tahun 2008 tentang Rehabilitasi dan Reklamasi Hutan.

Peraturan Pemerintah Nomor 105 Tahun 2015 tentang Perubahan Kedua atas Peraturan Pemerintah Nomor 24 Tahun 2010 tentang Penggunaan Kawasan Hutan.

Peraturan Presiden Nomor 28 Tahun 2011 tentang Penggunaan Kawasan Hutan Lindung untuk Penambangan Bawah Tanah.

Rodrigues, R. R., Gandolfi, S., Nave, A. G., ...., \& Brancalion, P. H. (2011). Large-scale ecological restoration of high-diversity tropical forests in SE Brazil. Forest Ecology and Management, 261(10), 1605-1613.

Saturi, S. (2013, September 22). Tambang kuasai 7 juta hektar lahan di Kaltim. Mongabay Indonesia. Retrieved 23 Februari 2017 from http://www. mongabay.co.id/2013/09/22/tambang-kuasai7-juta-hektar-lahan-di-kaltim/

Schlaepfer, M. A., Sax, D. F., \& Olden, J. D. (2011). The potential conservation value of nonnative species. Conservation Biology, 25(3), 428-437.
Suding, K. N. (2011). Toward an era of restoration in ecology: Successes, failures, and opportunities ahead. Annual Review of Ecology, Evolution, and Systematics, 42(1), 465.

The IUCN Red List of Threatened Species. (2016). IUCN definition-English-French. IUCN glossary definitions. Retrieved 23 Februari 2017 from https://www.iucn.org/downloads/ en_iucn_glossary_definitions.pdf

Undang-undang Nomor 41 Tahun 1999 tentang Kehutanan.

Undang-undang Nomor 4 Tahun 2009 tentang Pertambangan Mineral dan Batubara.

Vilà, M., Espinar, J L., Hejda, M., ....., \& Pyšek, P. (2011). Ecological impacts of invasive alien plants: A meta-analysis of their effects on species, communities and ecosystems. Ecology letters, 14(7), 702-708.

Yassir, I dan R. M. Omon. 2009. Pemilihan jenisjenis pohon potensial untuk mendukung kegiatan restorasi lahan tambang melalui pendekatan ekologis. Prosiding Workshop IPTEK Penyelamatan Hutan Melalui Rehabilitasi Lahan Pasca tambang Batubara pp: 64-76. Samarinda: Balai Besar Penelitian Dipterokarpa. 